Oktober 2018 Volume 2 No 1

\title{
ANALISIS TATANIAGA IKAN BANDENG DI KECAMATAN SAMUDERA KABUPATEN ACEH UTARA
}

\section{ANALYSIS OF TATANIAGA FISH BANDENG IN SAMUDERA DISTRICT NORTH ACEH DISTRICT}

\author{
Muhammad Authar MD \\ Program Studi Agribisnis \\ Universitas Malikussaleh \\ Email. authar@yahoo.co.id
}

\begin{abstract}
Abstrak
Tujuan penelitian adalah untuk menganalisis besarnya marjin pemasaran dan share harga yang diterima petani dan menganalisis besarnya rasio keuntungan dan biaya. Metode analisa data dalam penelitian dalam penelitian ini digunakan analisis tataniaga untuk mengetahui share harga, marjin pemasaran, share biaya, share keuntungan antara lembaga pemasaran.Hasil penelitian adalah Marjin pemasaran pada setiap saluran pemasaran yang ada besarnya bervariasi dan distribusinya tidak merata. Menurut analisis tataniaga, maka diketahui bahwa marjin pemasaran pada semua saluran pemasaran besarnya bervariasi. Pada saluran pertama marjinnya sebesar Rp. 5500,-, saluran kedua Rp. 6000,-, saluran ketiga Rp 4500,- dan saluran keempat Rp 5000,-.Share harga yang diterima petambak pada saluran pertama adalah 74,72\%, saluran kedua 72,73\%, saluran ketiga 78,05\% dan pada saluran keempat 76,19\%.Rasio keuntungan dan biaya besarnya juga bervariasi. Pada saluran pertama: rasio (K/B) untuk petambak adalah 0,18 , pedagang pengumpul desa 1,08, pedagang pengumpul kecamatan 1,08, pedagang pengumpul kabupaten 3,00 dan pedagang pengecer lokal 5,67. Pada saluran kedua: rasio (K/B) untuk petambak 0,18 , pedagang pengumpul desa 1,08 , pedagang pengumpul kecamatan 1,34 , pedagang pengumpul kabupaten 5,67 dan pedagang pengecer luar daerah 11,50. Pada saluran ketiga: rasio (K/B) untuk petambak 0,18, pedagang pengumpul kecamatan 1,34, pedagang pengumpul kabupaten 5,00 dan pedagang pengecer lokal 9,00.Pada saluran keempat: rasio (K/B) untuk petambak 0,18, pedagang pengumpul kecamatan 1,34, pedagang pengumpul kabupaten 5,67, pedagang pengecer luar daerah 15,67.
\end{abstract}

Kata kunci: Ikan Bandeng, Saluran Pemasaran dan Marjin Pemasaran

\begin{abstract}
The purpose of this study was to analyze the magnitude of the marketing margin and share price received by farmers, and to analyze the ratio of benefit to cost. Data analysis method in this research is by using a business administration analysis to determine the share price, the marketing margin, share costs, share of profit between marketing institutions.Based on analysis of business administration is known that the marketing margin on all marketing channels is varied in magnitude. In the first channel the marketing margin is $\mathrm{Rp} 5500$, Rp 6000 in the second channel, Rp 4500 in the third channel, and Rp 5000 in the fourth channel. Share price received by the owner of the pond in the first channel is $74.72 \%, 72.73 \%$ in the second channel, $78.05 \%$ in the third channel, and $76.19 \%$ in the fourth channel. Ratio of profit to cost is also varied magnitude. In the first channel: ratio of profit to cost $(\mathrm{P} / \mathrm{C})$ was 0.18 for the owner of the pond, 1.08 for collecting traders of village, 1.08 for collecting traders of the district, 3.00 for collecting traders of regency, and 11.50 for retailers outside the area. In the second channel: ratio of profit to cost (P / C) was 0.18 for the owner of the pond, 1.08 for collecting traders of village, 1.34 for collecting traders of the district, 5.67 for collecting traders of regency, and 11.50 for retailers outside the area. In the third channel: ratio of profit to cost (P / C) was 0.18 for the owner of the pond, 1.34 for collecting traders of the district, 5.67 for collecting traders of regency, and 15.67 for retailers outside the area.
\end{abstract}

Keywords: Milkfish, Marketing Channel, Marketing Margin

\section{A. PENDAhUluan}

Kabupaten Aceh Utara mempunyai sumber daya perikanan yang cukup besar sehingga dapat merupakan modal dasar bagi usaha untuk meningkatkan produksi perikanan. Sumber daya tersebut terdapat hampir di semua Kecamatan yang memiliki perairan laut, tambak dan kolam yang dapat mendukung peningkatan usaha budidaya. Berdasarkan data yang diperoleh dari Dinas
Kelautan dan Perikanan Kabupaten Aceh Utara, luas areal perikanan tambak menurut teknologi di Kabupaten Aceh Utara yaitu 10.779,63 Ha, dimana luas areal tambak secara tradisional 9.170,17 Ha dan semi intensif $1.609,46 \mathrm{Ha}$ yang tersebar di 27 Kecamatan.

Diantara 27 Kecamatan yang ada di Kabupaten Aceh utara, luas lahan dan produksi ikan 
bandeng di Kecamatan Samudera merupakan nomor tiga terbesar di Kabupaten Aceh Utara. Berikut adalah tabel luas areal dan produksi ikan bandeng di Kecamatan Samudera pada tahun 2008 dan 2009.luas areal tambak di Kecamatan Samudera pada tahun 2008 sebesar 946,00 Ha mampu menghasilkan 26,43 ton, dan pada tahun 2009 luas areal tambak meningkat yaitu 948,18 Ha, sedangkan produksi yang dihasilkan menurun menjadi 18,37 ton.

Perbedaan tingkat produksi dalam suatu kegiatan usahatani tambak disebabkan oleh beberapa faktor, diantaranya pada penggunaan faktor input (modal, luas lahan, tenaga kerja, nener/gelondongan, pupuk, pestisida, pakan dan lain-lain) yang memadai dan juga kondisi alam yang sesuai. Selain itu, teknik budidaya yang cocok sangat diperlukan dalam menentukan kualitas dan kuantitas output (ikan bandeng) dalam usaha pertambakan.

Namun peningkatan produksi belum menjamin terjadinya peningkatan pendapatan petani yang proporsional karena pendapatan petani selain dipengaruhi oleh besarnya produksi juga dipengaruhi oleh sistem pemasaran yang efisien, harga komoditas yang layak dan kemampuan manajemen usahatani.Sehubungan dengan hal tersebut maka dalam rangka meningkatkan pendapatan petani, perlu diimbangi dengan sistem pemasaran yang menguntungkan petani ${ }^{1}$.Pada saat ini petambak berproduksi bukan hanya untuk dikonsumsi sendiri tapi juga untuk dijual kepada orang lain sehingga aktivitas pemasaran sangatlah penting.

Salah satu aspek pemasaran yang diteliti dalam penelitian ini adalah mengidentifikasi penampilan pasar (market performance) pada pemasaran bandeng di kecamatan Samudera kabupaten Aceh Utara., penampilan pasar (market performance) merupakan salah satu aspek pemasaran yang penting dalam menilai seberapa baik aktivitas pemasaran memberikan kontribusi terhadap kesejahteraan petambak maupun pedagang. Market performance juga bisa menunjukkan seberapa baik sebuah proses pemasaran berjalan ${ }^{2}$

Melalui analisis penampilan pasar dapat diketahui bagaimanakah marjin pemasarannya, share harga yang diterima petambak, share biaya dan keuntungan antara lembaga pemasaran yang terlibat serta pengembalian modal antara lembaga pemasaran. Oleh sebab itu maka penelitian tentang penampilan pasar pada pemasaran ikan Bandeng di Kecamatan Samudera, Kabupaten Aceh Utara dirasa perlu untuk dilakukan agar dapat menunjukkan apakah proses pemasaran di daerah tersebut telah berjalan dengan baik.
Berdasarkan latar belakang tersebut, maka dalam penelitian ini dapat disimpulkan beberapa permasalahan pokok yang akan dibahas, yaitu:

1. Berapa besarnya marjin pemasaran dan share harga yang diterima petambak

2. Berapa besarnya rasio share keuntungan dan biaya serta pengembalian modal pada berbagai tingkat lembaga pemasaran yang terlibat dalam kegiatan pemasaran ikan Bandeng di daerah penelitian.

\section{B. METODE PENELITIAN}

Penelitian ini dilakukan di Kecamatan Samudera Kabupaten Aceh Utara pada sistem budidaya tradisional dan semi intensif.Pemilihan Lokasi dilakukan secara sengaja (purposive) dengan pertimbangan bahwa Kecamatan Samudera Penentuan lokasi ini dilakukan secara sengaja (purposive).Dipilihnya lokasi ini karena Kecamatan Samudera merupakan daerah penghasil bandeng(Chanos chanosforskal) terbesar nomor tiga di Kabupaten Aceh Utara Provinsi Aceh.

\section{Metode Penentuan Sampel}

Penentuan petambak responden dilakukan secara acak sederhana (simple random sampling) di kecamatan Samudera dengan kriteria sampel yaitu petambak yang melakukan usaha budidaya Bandeng yang luas tambaknya minimal 0,5 Ha. Dari populasi petambak yang ada di kecamatan Samudera sebanyak 130 orang diambil sampel sebanyak 50 persen yaitu sejumlah 65 orang petambak. Menurut Parel et al. (1972) sebaiknya jumlah sampel tidak kurang dari 30 dan disesuaikan dengan kemampuan keuangan, keterbatasan tenaga dan waktu. Penentuan lembaga pemasaran dilakukan dengan cara snow ball sampling yaitu berdasarkan informasi dari petambak kepada siapa komoditas itu dijual.

\section{Metode Pengumpulan Data}

Data yang dikumpulkan dalam penelitian ini adalah berupa data primer dan data sekunder. Data primer diperoleh dari petambak dan lembagalembaga pemasaran yang terlibat di dalam pemasaran ikan Bandeng. Data primer ini dikumpulkan melalui wawancara dengan menggunakan daftar pertanyaan untuk petambak dan lembaga pemasaran yang telah dipersiapkan sebelumnya. Data sekunder diperoleh dari data yang bersumber dari Dinas Perikanan KabupatenAceh Utara serta instansi lain yang terkait baik secara formal maupun informal.

\section{Metode Analisis Data}

Dalam penelitian ini digunakan analisis market performance (penampilan pasar) untuk 


\section{ANALISIS TATANIAGA IKAN BANDENG}

mengetahui share harga, marjin pemasaran, share biaya, share keuntungan dan tingkat pengembalian atas modal antara lembaga pemasaran. Untuk menganalisis penampilan pasar ada beberapa pendekatan yang bisa digunakan yaitu dengan menghitung marjin pemasaran, share harga, share biaya dan keuntungan serta tingkat pengembalian modal antara lembaga pemasaran. Beberapa alat analisis yang bisa digunakan untuk melihat penampilan pasar adalah:

\section{a. Marjin Pemasaran}

$\mathbf{M p}=\mathbf{P r}-\mathbf{P f}$

Atau :

$\mathrm{Mp}=\sum_{\mathrm{i}=1}^{\mathrm{n}} \mathrm{Bpi}+\sum_{\mathrm{i}=1}^{\mathrm{n}} \mathrm{Kpi}$

n

Bpi $=\sum_{\mathrm{i}=1}$ bij

Kpi $=$ Pij $-P b i-\sum$ bij

Dimana :

$\mathrm{Mp}=$ Marjin pemasaran $(\mathrm{Rp} / \mathrm{kg})$

$\operatorname{Pr}=$ Harga eceran pada konsumen $(\mathrm{Rp} / \mathrm{kg})$

$\mathrm{Pf}=$ Harga pada petani produsen $(\mathrm{Rp} / \mathrm{kg})$

Bpi = Biaya lembaga pemasaran ke-i $(\mathrm{Rp} / \mathrm{kg})$

Kpi = Keuntungan pemasaran $\mathrm{ke}-\mathrm{i}(\mathrm{Rp} / \mathrm{kg})$

$\mathrm{Pij}=$ Harga jual lembaga pemasaran $\mathrm{ke}-\mathrm{i}(\mathrm{Rp} / \mathrm{kg})$

$\mathrm{Pbi}=$ Harga beli lembaga pemasaran ke-i $(\mathrm{Rp} / \mathrm{kg})$

bij = Biaya pemasaran lembaga pemasaran ke-I dari berbagai jenis biaya mulai $\mathrm{j}=1$ sampai $\mathrm{j}=\mathrm{n}(\mathrm{Rp} / \mathrm{kg})$

b. Share Harga yang Diterima Petambak

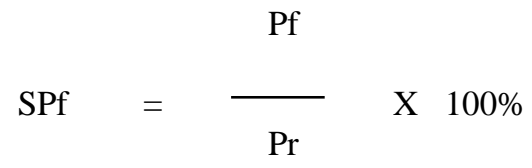

Keterangan :

$\begin{array}{lll}\mathrm{SPf} & = & \text { Share harga di tingkat petambak } \\ \mathrm{Pf} & = & \text { Harga di tingkat petambak } \\ \mathrm{Pr} & = & \text { Harga di tingkat konsumen }\end{array}$

c. Rasio Share Keuntungan dan Share Biaya Pemasaran

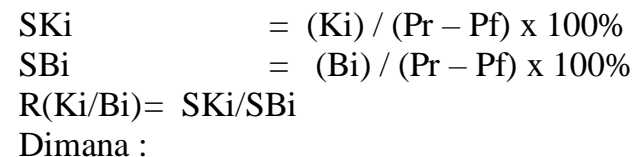

SKi $=$ Share keuntungan lembaga pemasaran ke-i

$\mathrm{SBi}=$ Share biaya pemasaran ke-i

$\mathrm{R}(\mathrm{Ki} / \mathrm{Bi})=\quad$ Rasio share keuntungan dan biaya pemasaran

\section{HASIL dan PEMBAHASAN}

\section{Sistem Pemasaran}

Sistem pemasaran bandeng di Kecamatan Samudera, Kabupaten Aceh Utara ini dilakukan dengan sistem satuan rupiah per kilogram $(\mathrm{Rp} / \mathrm{Kg})$, dari seluruh petani responden dalam penelitian ini, semuanya menggunakan jasa lemabaga pemasaran untuk menyalurkan bandeng hingga sampai ke tangan konsumen. Ada petani tambak yang memasarkan bandengnya melalui pedagang pengumpul desa dan juga yang langsung menjualnya ke pedagang pengumpul kecamatan kemudian pedagang pengumpul kecamatan yang menyalurkannya ke pedagang pengumpul kabupaten.Tidak ada petani tambak yang menjual hasil panennya langsung pada konsumen, petani tambak lebih memilih menggunakan lembaga pemasaran untuk memasarkan hasil panennya.

Adanya beberapa saluran pemasaran ini menyebabkan biaya pemasaran yang bervariasi dan keuntungan yang bervariasi pula.Biaya pemasaran yang dikeluarkan tiap lembaga pemasaran besarnya bervariasi tergantung dari fungsi dan jasa pemasaran yang dilakukannya demikian juga dengan tingkat keuntungan.

\section{Saluran Pemasaran}

Ada beberapa lembaga pemasaran yang terlibat dalam pemasaran bandeng dari pantai tambak di Kecamatan Samudera hingga ke tangan konsumen.Lembaga pemasaran tersebut adalah pedagang pengumpul desa, pedagang pengumpul kecamatan, pedagang pengumpul kabupaten dan pedagang pengecer lokal maupun luar daerah.Pada umumnya pedagang pengumpul ini sudah mempuyai langganan.Mereka dating ke tambak bandeng pada saat musimh panen tiba. Mereka datang ke tambak pada sore hari antara pukul 15.00 sampai 17.00 WIB.kemudian hasil panen bandeng langsung ditimbang dan diangkat dan diangut dengan alat transportasi (pick up atau truck) yang dibawa oleh pedagang pengumpul.

Untuk melihat lebih jelasnya saluran pemasaran dan lembaga pemasaran yang terlibat dalam pemasaran bandeng di kecamatan Samudera dapat dilihat pada gambar berikut ini: 


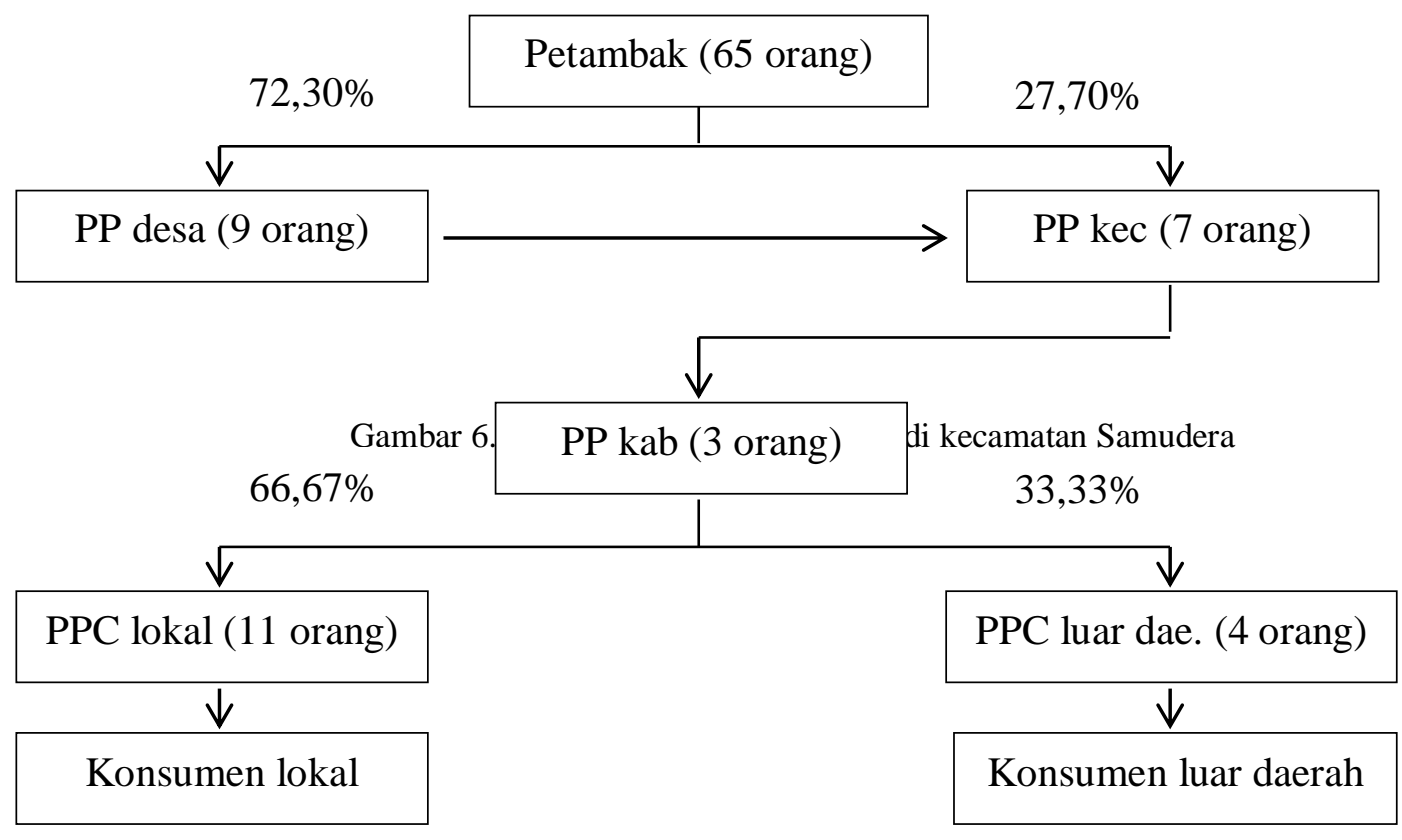

Dari gambar diatas dapat dilihat bahwa pemasaran bandeng di kecamatan Samudera mempunyai 4 (empat) saluran pemasaran yaitu sebagai berikut:

\section{Saluran I}

Petani tambak - pedagang pengumpul desa pedagang pengumpul kecamatan - pedagang pengumpul kabupaten - pedagang pengecer lokal.

\section{Saluran II}

Petani tambak - pedagang pengumpul desa pedagang pengumpul kecamatan - pedagang pengumpul kabupaten - pedagang pengecer luar daerah.

\section{Saluran III}

Petani tambak - pedagang pengumpul kecamatan pedagang pengumpul kabupaten - pedagang pengecer lokal.

\section{Saluran IV}

Petani tambak - pedagang pengumpul kecamatan pedagang pengumpul kabupaten - pedagang pengecer luar daerah.

Dari data hasil penelitian dapat dijelaskan bahwa 65 orang petani tambak responden, 47 orang $(72,30 \%)$ menjual hasil panen bandengnya ke

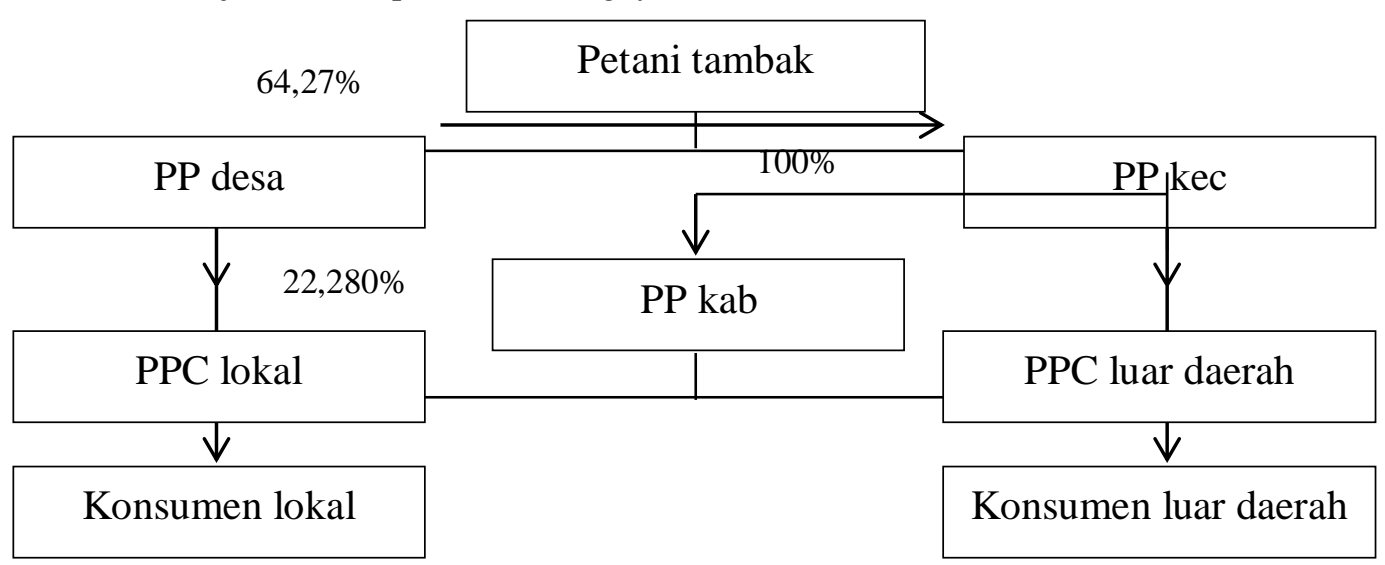

Gambar 7. Presentase produksi bandeng yang disalurkan pada tiap-tiap saluran pemasaran. 
Dari data hasil penelitian, produksi bandeng yang dihasilkan oleh petani tambak yang berjumlah 65 orang adalah sebanyak $39.000 \mathrm{~kg}$ $(100 \%)$. Dari jumlah tersebut yang dibeli oleh pedagang pengumpul desa sebanyak $28.197 \mathrm{~kg}$ $(64,27 \%)$ dan yang dibeli pedagang pengumpul kecamatan 13934,7 kg (35,73\%). Kemudian dari pedagang pengumpul desa semuanya $(100 \%)$ dijual ke pedagang pengumpul kecamatan kemudian pedagang pengumpul kecamatan menjual semuanya $(100 \%)$ ke pedagang pengumpul kabupaten. Selanjutnya pedagang pengumpul kabupaten menjual sebanyak 8689,2 kg (22,28\%) ke pedagang pengecer lokal dan menjual ke pedagang pengecer luar daerah sebanyak 30310,8 $\operatorname{kg}(77,72 \%)$.

Bandeng dari kecamatan Samudera ini ternyata lebih banyak dijual ke luar daerah.Hal ini terjadi karena konsumsi ikan bandeng di Kabupaten Aceh Utara relatif masih rendah selain itu harga ikan ini jika dijual ke luar daerah lebih tinggi dan sarana serta prasarana transportasi ke luar daerah sudah bagus, sehingga pengumpul kabupaten lebih memilih menjualnya ke pengecer luar daerah.

\subsubsection{Analisis Penampilan Pasar}

Dalam penelitian ini untuk mengetahui penampilan pasar dalam pemasaran bandeng analisis penampilan pasar dengan menghitung marjin pemasaran, share harga, share biaya dan share keuntungan dari tiap-tiap lembaga pemasaran.

\section{a. Marjin Pemasaran}

Marjin pemasaran dapat didefinisikan sebagai perbedaan harga yang dibayarkan oleh konsumen dengan harga yang diterima produsen, dengan kata lain marjin pemasaran merupakan selisih harga di tingkat konsumen dengan harga di tingkat produsen. Besarnya marjin pemasaran pada berbagai saluran pemasaran dapat berbeda, karena tergantung pada pendeknya saluran pemasaran dan aktivitas pemasaran yang dilaksanakan serta keuntungan yang diharapkan oleh lembaga pemasaran yang terlihat dalam proses pemasaran.

Pada tabel 8 berikut dapat dilihat hasil analisa marjin, distribusi marjin, share harga yang diterima petani serta rasio keuntungan dan biaya dalam pemasaran ikan bandeng.

Tabel 8. Marjin pemasaran, Distribusi Marjin, Share Harga yang diterima petani tambak, serta Rasio Keuntungn dan biaya pada Saluran I dalam Pemasaran Bandeng di Kecamatan Samudra Kabupaten Aceh Utara tahun 2013.

\begin{tabular}{|c|c|c|c|c|c|}
\hline Saluran & Lembaga Pemasaran & $\begin{array}{c}\text { Biaya dan Harga } \\
(\mathrm{Rp} / \mathrm{kg})\end{array}$ & $\begin{array}{c}\text { Distribusi } \\
\text { marjin }(\%)\end{array}$ & Share harga (\%) & $\begin{array}{l}\text { Rasio } \\
(\text { K/B })\end{array}$ \\
\hline \multirow{5}{*}{ I } & $\begin{array}{l}\text { Petani tambak } \\
\text { Biaya usaha tani } \\
\text { Harga jual } \\
\text { Keuntungan }\end{array}$ & $\begin{array}{c}14750 \\
16000 \\
1250\end{array}$ & & 74,42 & 0,08 \\
\hline & $\begin{array}{l}\text { PP desa } \\
\text { Biaya pemasaran } \\
\text { Harga beli } \\
\text { Harga jual } \\
\text { Keuntungan }\end{array}$ & $\begin{array}{c}720 \\
16000 \\
17500 \\
780\end{array}$ & $\begin{array}{l}13,09 \\
14,18\end{array}$ & & 1,08 \\
\hline & $\begin{array}{l}\text { PP kec } \\
\text { Biaya pemasaran } \\
\text { Harga beli } \\
\text { Harga jual } \\
\text { Keuntungan }\end{array}$ & $\begin{array}{c}640 \\
17500 \\
19000 \\
860\end{array}$ & $\begin{array}{l}11,64 \\
14,64\end{array}$ & & 1,34 \\
\hline & $\begin{array}{l}\frac{\text { PP kab }}{\text { Biaya pemasaran }} \\
\text { Harga beli } \\
\text { Harga jual } \\
\text { Keuntungan }\end{array}$ & $\begin{array}{c}250 \\
19000 \\
20000 \\
750\end{array}$ & $\begin{array}{r}4,55 \\
13,64\end{array}$ & & 3,00 \\
\hline & $\begin{array}{l}\text { PPC lokal } \\
\text { Biaya pemasaran } \\
\text { Harga beli } \\
\text { Harga jual } \\
\text { Keuntungan }\end{array}$ & $\begin{array}{c}150 \\
20500 \\
21500 \\
850\end{array}$ & $\begin{array}{r}2,73 \\
15,54\end{array}$ & & 5,67 \\
\hline Marjin & 5500 & & & & \\
\hline
\end{tabular}


Dari tabel 7 dapat diketahui bahwa pada saluran pemasaran yang pertama, marjin pemasarannya sebesar Rp 5500,-. Dari besarnya marjin tersebut didistribusikan untuk pedagang pengumpul desa pada biaya sebesar 13,09 persen dan keuntungannya sebesar 14,18 persen. Sedangkan untuk pedagang pengumpul kecamatan, pada biaya sebesar 11,64 persen dan keuntungannya 14,64 persen. Untuk pedagang pengumpul kabupaten, pada biaya sebesar 4,55 persen dan keuntungannya 13,64 persen. Kemudian untuk pedagang pengecer lokal pada biaya sebesar 2,73 persen dan keuntungannya 15,54 persen. Dengan demikian dapat diketahui bahwa biaya pemasaran terbesar dikeluarkan oleh pedagang pengumpul desa karena mereka harus mengambil langsung bandeng dari tambak yang letaknya tersebar sehingga biaya transportasinya menjadi lebih besar.Selain itu sortasi bandeng juga dilakukan oleh pedagang pengumpul desa.Walaupun nampaknya keuntungan terbesar diperoleh oleh pedagang pengumpul kecamatan namun jika terlihat dari rasio keuntungan dan biaya, maka nilai rasio terbesar diperoleh oleh pedagang pengecer lokal karena biaya pemasaran yang dikeluarkannya paling kecil.

Pada saluran kedua, marjin pemasaran, share harga, share biaya dan keuntungan dapat dilihat pada Tabel 9.

Tabel 9. Marjin pemasaran, Distribusi Marjin, Share Harga yang diterima petani tambak, serta Rasio Keuntungn dan biaya pada Saluran II dalam Pemasaran Bandeng di Kecamatan Samudra Kabupaten Aceh Utara tahun 2013.

\begin{tabular}{|c|c|c|c|c|c|}
\hline Saluran & $\begin{array}{c}\text { Lembaga } \\
\text { Pemasaran }\end{array}$ & $\begin{array}{c}\text { Biaya dan } \\
\text { Harga }(\mathrm{Rp} / \mathrm{kg})\end{array}$ & $\begin{array}{c}\text { Distribusi } \\
\text { marjin }(\%)\end{array}$ & $\begin{array}{c}\text { Share } \\
\text { harga }(\%)\end{array}$ & $\begin{array}{l}\text { Rasio } \\
(\mathbf{K} / \mathbf{B})\end{array}$ \\
\hline & Petambak & & & & \\
\hline & $\overline{\text { Biaya usaha tani }}$ & 14750 & & 72,73 & 0,18 \\
\hline & Harga jual & 16000 & & & \\
\hline & Keuntungan & 1250 & & & \\
\hline & PP desa & & & & \\
\hline & $\overline{\text { Biaya pemasaran }}$ & 720 & 12,00 & & 1,08 \\
\hline & Harga beli & 16000 & & & \\
\hline & Harga jual & 17500 & & & \\
\hline & Keuntungan & 780 & 13,00 & & \\
\hline \multirow{15}{*}{ II } & PP kec & & & & \\
\hline & Biaya pemasaran & 640 & 10,67 & & 1,34 \\
\hline & Harga beli & 17500 & & & \\
\hline & Harga jual & 19000 & & & \\
\hline & Keuntungan & 860 & 14,33 & & \\
\hline & PP kab & & & & \\
\hline & Biaya pemasaran & 250 & 4,92 & & 5,67 \\
\hline & Harga beli & 19000 & & & \\
\hline & Harga jual & 20000 & & & \\
\hline & Keuntungan & 750 & 21,25 & & \\
\hline & PPC luar daerah & & & & \\
\hline & Biaya pemasaran & 120 & 2,00 & & 11,50 \\
\hline & Harga beli & 20500 & & & \\
\hline & Harga jual & 22000 & & & \\
\hline & Keuntungan & 1380 & 23,00 & & \\
\hline Marjin & 6000 & & & & \\
\hline
\end{tabular}

Dari tabel 8 dapat diketahui bahwa pada saluran pemasaran yang kedua , marjin pemasarannya sebesar Rp 6.000,-. Dari besarnya marjin tersebut didistribusikan untuk pedagang pengumpul desa pada biaya sebesar 12,00 persen dan keuntungannya sebesar 13,00 persen. Sedangkan untuk pedagang pengumpul kecamatan, pada biaya sebesar 10,67 persen dan keuntungannya 14,33 persen. Untuk pedagang pengumpul kabupaten, pada biaya sebesar 4,92 persen dan keuntungannya 21,25 persen. Kemudian untuk pedagang pengecer lokal pada biaya sebesar 2,00 persen dan keuntungannya 23,00 persen. Dengan demikian dapat diketahui bahwa biaya pemasaran terbesar dikeluarkan oleh pedagang pengumpul desa karena mereka harus mengambil 


\section{ANALISIS TATANIAGA IKAN BANDENG}

langsung bandeng dari tambak yang letaknya tersebar sehingga biaya transportasinya menjadi lebih besar.Selain itu sortasi bandeng juga dilakukan oleh pedagang pengumpul desa.Sedangkan keuntungan terbesar diperoleh oleh pedagang pengecer luar daerah karena tidak banyak aktivitas pemasaran yang dilakukannya.

Untuk saluran ketiga marjin pemasaran, share harga, share biaya dan keuntungan dapat dilihat pada Tabel 10 berikut ini:

Tabel 10. Marjin pemasaran, Distribusi Marjin, Share Harga yang diterima petani tambak, serta Rasio KEuntungn dan biaya pada Saluran III dalam Pemasaran Bandeng di Kecamatan Samudra Kabupaten Aceh Utara tahun 2013.

\begin{tabular}{|c|c|c|c|c|c|}
\hline Saluran & Lembaga Pemasaran & $\begin{array}{c}\text { Biaya dan Harga } \\
(\mathrm{Rp} / \mathrm{kg})\end{array}$ & $\begin{array}{c}\text { Distribusi } \\
\text { marjin }(\%)\end{array}$ & $\begin{array}{c}\text { Share } \\
\text { harga } \\
(\%)\end{array}$ & $\begin{array}{l}\text { Rasio } \\
\text { (K/B) }\end{array}$ \\
\hline & Petambak & & & & \\
\hline & $\overline{\text { Biaya usaha tani }}$ & 14750 & & 78,05 & 0,18 \\
\hline & Harga jual & 16000 & & & \\
\hline & Keuntungan & 980 & & & \\
\hline & PP kec & & & & \\
\hline & $\overline{\text { Biaya pemasaran }}$ & 640 & 14,22 & & 1,34 \\
\hline & Harga beli & 16000 & & & \\
\hline & Harga jual & 17500 & & & \\
\hline & Keuntungan & 860 & 19,11 & & \\
\hline \multirow[t]{10}{*}{ III } & $\underline{\mathrm{PP} \mathrm{kab}}$ & & & & \\
\hline & $\overline{\text { Biaya pemasaran }}$ & 250 & 5,56 & & 5,00 \\
\hline & Harga beli & 17500 & & & \\
\hline & Harga jual & 19000 & & & \\
\hline & Keuntungan & 1250 & 27,78 & & \\
\hline & $\underline{\text { PPC lokal }}$ & & & & \\
\hline & $\overline{\text { Biaya pemasaran }}$ & 150 & 3,33 & & 9,00 \\
\hline & Harga beli & 19000 & & & \\
\hline & Harga jual & 20500 & & & \\
\hline & Keuntungan & 1350 & 30,00 & & \\
\hline Marjin & 4500 & & & & \\
\hline
\end{tabular}

Dari tabel 9 dapat diketahui bahwa pada saluran pemasaran yang ketiga, marjin pemasarannya sebesar Rp 4.500,-. Dari besarnya marjin tersebut didistribusikan untuk pedagang pengumpul kecamatan, pada biaya sebesar 14,22 persen dan keuntungannya 19,11 persen. Untuk pedagang pengumpul kabupaten, pada biaya sebesar 5,56 persen dan keuntungannya 27,78 persen. Kemudian untuk pedagang pengecer lokal pada biaya sebesar 3,33 persen dan keuntungannya 30,00 persen. Dengan demikian dapat diketahui bahwa biaya pemasaran terbesar dikeluarkan oleh pedagang pengumpul kecamatan karena mereka harus mengambil langsung bandeng dari tambak yang letaknya tersebar sehingga biaya transportasinya menjadi lebih besar.Selain itu sortasi bandeng juga dilakukan oleh pedagang pengumpul kecamatan.Sedangkan keuntungan terbesar diperoleh oleh pedagang pengecer.

Untuk saluran ketiga marjin pemasaran, share harga, share biaya dan keuntungan dapat dilihat pada Tabel 11 . 
Tabel 11. Marjin pemasaran, Distribusi Marjin, Share Harga yang diterima petani tambak, serta Rasio KEuntungn dan biaya pada Saluran IV dalam Pemasaran Bandeng di Kecamatan Samudra Kabupaten Aceh Utara tahun 2013.

\begin{tabular}{|c|c|c|c|c|c|}
\hline Saluran & Lembaga Pemasaran & $\begin{array}{c}\text { Biaya dan Harga } \\
(\mathrm{Rp} / \mathrm{kg})\end{array}$ & $\begin{array}{c}\text { Distribusi } \\
\text { marjin }(\%)\end{array}$ & $\begin{array}{c}\text { Share } \\
\text { harga } \\
(\%)\end{array}$ & $\begin{array}{l}\text { Rasio } \\
(\mathrm{K} / \mathrm{B})\end{array}$ \\
\hline \multirow{19}{*}{ IV } & Petambak & & & \multirow{14}{*}{76,19} & \multirow{4}{*}{0,08} \\
\hline & $\overline{\text { Biaya usaha tani }}$ & 14750 & & & \\
\hline & Harga jual & 16000 & & & \\
\hline & Keuntungan & 1250 & & & \\
\hline & \multicolumn{2}{|l|}{ PP kec } & \multirow{4}{*}{12,80} & & \multirow{5}{*}{1,34} \\
\hline & $\overline{\text { Biaya pemasaran }}$ & 640 & & & \\
\hline & Harga beli & 16000 & & & \\
\hline & Harga jual & 17500 & & & \\
\hline & Keuntungan & 860 & 17,20 & & \\
\hline & \multicolumn{2}{|l|}{ PP kab } & \multirow{5}{*}{4,50} & & \multirow{5}{*}{5,67} \\
\hline & Biaya pemasaran & 225 & & & \\
\hline & Harga beli & 17500 & & & \\
\hline & Harga jual & 19000 & & & \\
\hline & Keuntungan & 1275 & & & \\
\hline & \multicolumn{2}{|l|}{ PPC luar daerah } & & & \multirow{5}{*}{15,67} \\
\hline & $\overline{\text { Biaya pemasaran }}$ & 120 & 2,40 & & \\
\hline & Harga beli & 19000 & & & \\
\hline & Harga jual & 21000 & & & \\
\hline & Keuntungan & 1880 & 37,60 & & \\
\hline Marjin & 5000 & & & & \\
\hline
\end{tabular}

Dari tabel 10 dapat diketahui bahwa pada saluran pemasaran yang pertama, marjin pemasarannya sebesar Rp 5.000,-. Dari besarnya marjin tersebut didistribusikan untuk pedagang pengumpul kecamatan pada biaya sebesar 12,80 persen dan keuntungannya 17,20 persen. Untuk pedagang pengumpul kabupaten, pada biaya sebesar 4,50 persen dan keuntungannya 25,50 persen. Kemudian untuk pedagang pengecer luar daerah pada biaya sebesar 2,40 persen dan keuntungannya 37,60 persen. Dengan demikian dapat diketahui bahwa biaya pemasaran terbesar dikeluarkan oleh pedagang pengumpul kecamatan karena mereka harus mengambil langsung bandeng dari tambak yang letaknya tersebar sehingga biaya transportasinya menjadi lebih besar.Selain itu sortasi bandeng juga dilakukan oleh pedagang pengumpul kecamatan.Sedangkan keuntungan terbesar diperoleh oleh pedagang pengecer luar daerah.

Untuk mengetahui perbandingan besarnya marjin pemasaran dari keempat saluran pemasaran yang ada maka dapat dilihat dari Tabel 12 .

Tabel 12. Perbandingan Marjin Pemasaran dari Empat Saluran Pemasaran Bandeng di Kecamatan Samudera Kabupaten Aceh Utara.

\begin{tabular}{lccc}
\hline \multicolumn{1}{c}{ Saluran pemasaran } & Marjin (Rp/kg) & Presentase (\%) \\
\hline & I & 5500 & 26,19 \\
& II & 6000 & 28,57 \\
& III & 4500 & 21,43 \\
& IV & 5000 & 23,81 \\
\hline Total & & 21000 & 100 \\
Rata-rata & 5250 & 25 \\
\hline
\end{tabular}

Dari Tabel 11 diatas dapat diketahui bahwa marjin pemasaran dari keempat saluran pemasaran di Kecamatan Samudera distribusinya tidak merata. Marjin terbesar terdapat pada saluran pemasaran kedua yaitu sebesar 28,5. Hal ini terjadi karena saluran tersebut lebih panjang dan 
pemasaran produknya keluar daerah sehingga memerlukan biaya transportasi yang lebih besar.

\section{b. Share Harga yang diterima petani tambak}

Jika dilihat dari keempat saluran pemasaran yang adam, maka share harga yang diterima oleh petambak besarnya bervariasi. Bila saluran pemasaran yang dilalui relatif panjang, maka akan memperbesar marjin pemasaran sehingga share harga yang diterima petani tambak dari harga yang dibayarkan konsumen akan menjadi semakin kecil. Untuk melihat lebih jelas perbandingan share harga dari keempat saluran dapat dilihat pada tabel 13 dibawah ini.

Tabel 13. Perbandingan Share Harga dari Empat Saluran Pemasaran Bandeng di Kecamatan Samudera Kabupaten Aceh Utara.

\begin{tabular}{lccc}
\hline \multicolumn{2}{c}{ Saluran pemasaran } & Share Harga (\%) & Presentase (\%) \\
\hline & I & 74,72 & 24,77 \\
& II & 72,73 & 24,11 \\
& III & 78,05 & 25,87 \\
& IV & 76,19 & 25,25 \\
\hline Total & & 301,69 & 100 \\
Rata-rata & 75,42 & 25 \\
\hline
\end{tabular}

Dengan melihat Tabel 13 dapat diketahui bahwa share harga terbesar yang diterima petambak terdapat pada saluran ketiga, kemudian saluran keempat, kesatu dan yang paling rendah pada saluran kedua.Hal ini terjadi karena saluran pemasarannya panjang dan produknya dipasarkan keluar daerah sehingga biaya transportasi yang dikeluarkan menjadi lebih besar.

Share harga yang diterima petani tambak sesungguhnya merupakan biaya produksi dan keuntungan. Bagian keuntungan ini dapat ditafsirkan sebagai sumbangan pendapatan bagi kesejahteraan keluarga petani tambak.Melihat kondisi ini dapat dikatakan bahwa share harga yang diterima petani tambak masih relatif kecil, dengan semakin besarnya marjin ternyata membuktikan bahwa share harga yang diterima petani tambak semakin kecil. Pada saluran I dan II, share harga dibawah rata-rata walaupun saluran I lebih besar dari saluran II. Hal ini membuktikan bahwa semakin kecil marjin pemasaran maka share harga yang diterima petambak akan semakin besar.

\section{c. Rasio Keuntungan dan Biaya}

Untuk mengetahui besarnya rasio keuntungan dan biaya pemasaran pada masingmasing saluran pemasaran dapat dilihat pada Tabel 14 dibawah ini.

Tabel 14. Rasio keuntungan dan biaya pada masing-masing tingkat pasar di berbagai Saluran Pemasaran Bandeng di Kecamatan Samudera Kabupaten Aceh Utara.

\begin{tabular}{ccccccc}
\hline \multirow{2}{*}{$\begin{array}{c}\text { Saluran } \\
\text { pemasaran }\end{array}$} & Petambak & PP desa & PP kec & PP kab & PPC lokal & $\begin{array}{c}\text { PPC luar } \\
\text { daerah }\end{array}$ \\
\cline { 2 - 6 } & 0,18 & 1,08 & 1,08 & 3,00 & 5,67 & - \\
I & 0,18 & 1,08 & 1,34 & 5,67 & - & 11,50 \\
II & 0,18 & - & 1,34 & 5,00 & 9,00 & - \\
III & 0,18 & - & 1,34 & 5,67 & - & 15,67 \\
IV & & & & & &
\end{tabular}

Pada tabel diatas dapat dilihat besarnya rasio keuntungan dan biaya yang cukup bervariasi pada masing-masing tingkat pasar di berbagai saluran pemasaran bandeng. Rasio keuntungan dan biaya yang ada di tingkat petambak adalah 0,18 dan ini sama pada semua saluran. Hal ini disebabkan karena penelitian ini hanya dilakukan pada satu kecamatan sehingga harga jual bandeng di tingkat petambak relatif sama. Rasio keuntungan dan biaya yang diperoleh petani adalah sebesar 0,18 artinya setiap pengeluaran biaya sebesar satu satuan maka akan diperoleh kentungan sebesar 0,18 satuan. Pada tingkat pedagang pengumpul desa rasio keunungan dan biayanya sama yaitu sebesar 1,08. Hal ini disebabkan karena pada saluran pertama dan kedua pedagang pengumpul desa langsung mengambil banding dari petambak sehingga biaya dan keuntungan yang diperoleh relatif sama. Pada penambahan biaya sebesar satu satuan maka pedagang pengumpul desa akan mendapatkan tambahan keuntungan sebesar 1,08 di tingkat pedagang 1,08 artinya setiap penambahan biaya sebesar 1 satuan akan menjadi penambahan keuntungan saluran sebesar 1,08 satuan dan pada satu, pedagang pengumpul kecamatan mengambil bandeng dari pedagang pengumpul desa. Pada saluran kedua, ketiga dan keempat besarnya rasio keuntungan dan biaya sama yaitu 1,34. Hal ini terjadi karena pedagang pengumpul kecamatan mengambil bandeng langsung dari petambak. Rasio 
sebesar 1,34 artinya dengan menambah biaya sebesar satu satuan maka akan diperoleh tambahan keuntungan sebesar 1,34. Di tingkat pedagang pengumpul kabupaten, rasio terbesar terdapat pada saluran kedua dan keempat yaitu 5,67 kemudian diikuti pedagang pengumpul kabupaten pada saluran ketiga, dan terakhir yang pertama. Hal ini terjadi karena pedagang pengumpul kabupaten pada saluran kedua dan keempat biaya pemasarannya kecil hanya mengeluarkan biaya transportasi sehingga keuntungan meningkat yang menyebabkan rasio keuntungan terhadap biaya juga meningkat.

Demikian pula pada tingkat pedagang pengecer lokal, saluran ketiga lebih besar dari saluran pertama karena biaya transportasi yang dikeluarkannya lebih kecil.Pada tingkat pedagang pengecer luar daerah saluran keempat paling besar rasionya karena pada tingkat ini tidak banyak aktivitas pemasaran yang dilakukan dan tidak ada biaya transportasi.Karena pedagang pengumpul kabupatenlah yang mendatangi pedagang pengecer luar daerah di pasar ikan yang ada di luar daerah dan pedagang pengecer luar daerah ini langsung menjual bandengnya ke konsumen dengan harga yang lebih tinggi dibandingkan di tingkat lokal.

Dari semua saluran tersebut, dapat diketahui bahwa sistem pemasaran bandeng di kecamatan Samudera belum baik karena belum mampu menyampaikan hasil dari petani tambak produsen kepada konsumen dengan biaya yang murah dan belum mampu mengadakan pembagian yang adil dari keseluruhan harga yang dibayarkan konsumen terakhir kepada semua pihak yang terlibat dalam kegiatan pemasaran tersebut

\section{KESIMPULAN DAN SARAN Kesimpulan}

Dari analisis yang telah dilakukan oleh peneliti maka diambil beberapa kesimpulan tentang tataniaga pmasaran ikan bandeng di Kecamatan Samudera Kabupaten Aceh Utara yaitu:

1. Marjin pemasaran pada tiap saluran pemasaran yang ada besarnya bervariasi dan distribusinya tidak merata. Menurut analisis tataniaga, maka diketahui bahwa marjin pemasaran pada semua saluran pemasaran besarnya bervariasi. Pada saluran pertama marjinnya sebesar Rp. 5500,-, saluran kedua Rp. 6000,-, saluran ketiga Rp 4500,- dan saluran keempat Rp 5000,-.

Share harga yang diterima petambak pada saluran pertama adalah $74,72 \%$, saluran kedua $72,73 \%$, saluran ketiga $78,05 \%$ dan pada saluran keempat $76,19 \%$.

2. Rasio keuntungan dan biaya besarnya juga bervariasi. Pada saluran pertama: rasio (K/B) untuk petambak adalah 0,18 , pedagang pengumpul desa 1,08 , pedagang pengumpul kecamatan 1,08, pedagang pengumpul kabupaten 3,00 dan pedagang pengecer lokal 5,67. Pada saluran kedua: rasio (K/B) untuk petambak 0,18, pedagang pengumpul desa 1,08 , pedagang pengumpul kecamatan 1,34, pedagang pengumpul kabupaten 5,67 dan pedagang pengecer luar daerah 11,50. Pada saluran ketiga: rasio $(\mathrm{K} / \mathrm{B})$ untuk petambak 0,18 , pedagang pengumpul kecamatan 1,34, pedagang pengumpul kabupaten 5,00 dan pedagang pengecer lokal 9,00.

Pada saluran keempat: rasio (K/B) untuk petambak 0,18 , pedagang pengumpul kecamatan 1,34, pedagang pengumpul kabupaten 5,67, pedagang pengecer luar daerah 15,67 .

Dengan demikian berdasarkan hasil analisis tataniaga pemasaran ikan Bandeng, maka dapat dikatakan bahwa proses pemasaran bandeng di kecamatan Samudera Kabupaten Aceh Utara belum berjalan dengan baik dan belum efisien. Petani tambak masih menerima harga yang sama pada semua saluran pemasaran sehingga pendapatan petambak relatif masih rendah.

\section{Saran}

Beberapa saran yang penulis harapkan bisa bermanfaat untuk perbaikan pemasaran banding di daerah penelitian adalah:

1. Untuk memperkecil marjin pemasaran serta agar share harga yang diterima petani tambak meningkat maka perlu diupayakan saluran pemasaran yang lebih pendek.

2. Perlu dilakukan kerjasama berbagai pihak baik pemerintah, petani tambak serta pedagang, agar sistem pemasaran bandeng di Kecamatan Samudera Kabupaten Aceh Utara lebih efisien sehingga pendapatan petani tambak bisa meningkat.

Daftar Pustaka

Mosher A.T. 1978. Menggerakkan dan Membangun Pertanian. Yasaguna, Jakarta.

Anindita, Ratya. 2003. Dasar-dasar Pemasaran Hasil Pertanian. Fakultas Pertanian Universitas Brawijaya. Malang.

Kensuratih. 2015. Ilmu Usaha Tani. Penebaran Suadaya. Jakarta.

Sofyan, Assauri. 1987. Manajemen Pemasaran. Rajawali Pers. Jakarta.

Sugiono. 2013. Metode Penelitian. Bandung: Alfabeta. 